\title{
PERANCANGAN HARDWARE SISTEM MONITORING PORTABEL UNTUK MONITORING ARUS DAN TEGANGAN LISTRIK MENGGUNAKAN RASPBERRY PI
}

\author{
I Putu Bayu Negara ${ }^{1}$, I Made Arsa Suyadnya ${ }^{2}$, Nyoman Putra Sastra ${ }^{3}$ \\ ${ }^{1,2,3}$ Program Studi Teknik Elektro, Universitas Udayana \\ Bali, Indonesia
}

e-mail: bayu.tu@gmail.com, arsa.suyadnya@unud.ac.id, putra.sastra@unud.ac.id

\begin{abstract}
Abstrak
Sistem monitoring mencakup pengumpulan, pelaporan, dan tindakan atas informasi suatu proses yang sedang berlangsung di suatu ruangan. Salah satu hal yang dapat dimonitoring pada ruangan adalah tingkat penggunaan listrik. Pada penelitian ini, dilakukan perancangan hardware sistem monitoring portabel yang dapat memonitoring arus dan tegangan listrik AC. Desain hardware menggunakan prosessor Raspberry Pi untuk mengolah hasil pembacaan 4 buah sensor arus YHDC tipe SCT-013-000 dan sensor tegangan AC. Hardware dapat diakses melalui antarmuka konfigurasi berbasis web yang menampilkan konektivitas jaringan dan nilai dari sensor-sensor. Hasil pengujian sensor arus pada saluran listrik 3 fase RSTN dan pengujian sensor tegangan didapatkan bahwa LCD pada hardware dan antarmuka konfigurasi berbasis web telah berhasil menampilkan nilai pembacaan sensor-sensor. Hardware juga telah berhasil terhubung ke jaringan wireless "RUANGAN01" pada alamat IP 192.168.8.107. Keseluruhan fungsionalitas antarmuka konfigurasi hardware berbasis web seperti login, koneksi perangkat, konfigurasi "on" sensor, reboot, shutdown dan reset juga telah berfungsi dengan baik dan sesuai dengan rancangan.
\end{abstract}

Kata kunci: hardware, monitoring, raspberry pi, sensor

\begin{abstract}
The monitoring system includes collection, reporting, and action on the information of an ongoing process in a room. One of the things that can be monitored in the room is the level of electricity usage. In this research, undertake the hardware design of portable monitoring system that can monitor the current and voltage of $A C$ power. The hardware design uses Raspberry Pi processor to process the reading of 4 YHDC current sensor type SCT-013-000 and AC voltage sensor. Hardware can be accessed via a web-based configuration interface that displays network connectivity and the value of sensors. The results of testing the current sensors on the 3 phase RSTN power lines and testing the voltage sensor obtained that LCD on hardware and web-based configuration interface has successfully displayed the value of sensor readings. Hardware has also successfully connected to wireless network "ROOM01" on IP address 192.168.8.107. The overall functionality of the web-based hardware configuration interface such as login, device connection, "on" sensor configuration, reboot, shutdown and reset are also functioning properly and in accordance with the design.
\end{abstract}

Keywords : hardware, monitoring, raspberry pi, sensor

\section{PENDAHULUAN}

Secara umum sistem monitoring mencakup pengumpulan, pelaporan, dan tindakan atas informasi suatu proses yang sedang diimplementasikan (Mercy Corps, 2005). Pengumpulan data sistem monitoring biasanya melibatkan perangkat yang diterapkan pada suatu tempat atau ruangan dengan aktivitas yang padat. Salah satu hal yang dapat dimonitoring pada ruangan yakni tingkat penggunaan listrik. Banyaknya penggunaan listrik pada ruangan terkadang tidak diketahui secara detail dan mengakibatkan pemborosan energi listrik. Oleh karena itu dibutuhkan perangkat untuk melakukan monitoring Jurnal Sains dan Teknologi | 1 
penggunaan listrik yang dapat diaplikasikan dengan mudah serta mampu menampilkan informasi detail penggunaan listrik yang sedang digunakan.

Untuk memonitoring tingkat penggunaan listrik dibutuhkan informasi tegangan dan arus, serta perangkat yang dapat melakukan pembacaan dan menampilkan informasi tegangan dan arus secara jelas. Salah satu perangkat yang dapat digunakan untuk membuat sebuah perangkat atau hardware sistem monitoring adalah Raspberry $\mathrm{Pi}$. Raspberry $\mathrm{Pi}$ merupakan sebuah komputer mini yang bisa melakukan tugas ganda sebagai mikrokontroler dan sebagai komputer. Raspberry $\mathrm{Pi}$ menggunakan Operating System varian Linux. Raspberry $\mathrm{Pi}$ dapat digunakan sebagai web server yang dapat melayani permintaan pengguna melalui tampilan halaman web (Ignatius Prima Haryo Prabowo et al., 2014). Konsumsi daya Raspberry $\mathrm{Pi}$ juga sangat rendah yaitu 3.5 Watt. Terdapat pula port RJ45, sehingga memungkinkan Raspberry $\mathrm{Pi}$ terkoneksi dengan jaringan (Tauriq Djasa Permana, 2014). Raspberry Pi memiliki fasilitas General Purpose Input and Output (GPIO), dimana fungsi pin-pin GPIO dapat diatur sebagai input (masukan) maupun output (keluaran) (Edi Rakhman et al., 2014). Penelitian yang dilakukan oleh Irwan Dinata dan Wahri Sunanda (2015), mengimple-mentasikan wireless monitoring energi listrik berbasis web database untuk menggantikan sistem pengukuran energi listrik secara manual dan konvensional. Perangkat yang dirancang menggunakan processor Arduino UNO untuk mengolah hasil sensor serta Ethernet Shiled untuk terhubung jaringan. Perangkat yang dirancang terkoneksi ke jaringan masih menggunakan kabel dan belum adanya interface yang memudahkan konfigurasi perangkat.

Pada penelitian ini dirancang hardware yang menjalankan fungsi monitoring arus dan tegangan listrik $A C$ (Alternating Current) yang memiliki web interface untuk konfigurasi serta menampilkan nilai hasil monitoring. Hardware dirancang memiliki kemudahan pemasangan pada panel saluran instalasi listrik 3 fase tanpa perlu merubah kondisi instalasi. Hardware dirancang menggunakan processor Raspberry $\mathrm{Pi}$ dengan sumber daya yang berasal dari baterai. Konektivitas jaringan Raspberry $\mathrm{Pi}$ menggunakan kabel UTP dan USB WiFi Adapter. Bagian sensor menggunakan sensor arus YHDC tipe SCT-013-000 dan sensor tegangan AC. Pengolah data sensor-sensor menggunakan software Python dengan tampilan Liquid Crystal Display (LCD). Aplikasi web konfigurasi hardware diakses melalui alamat IP hardware. Perpaduan Raspberry $\mathrm{Pi}$, sensor-sensor dan software menghasilkan hardware sistem monitoring yang bersifat portabel. Konfigurasi hardware hanya melalui aplikasi web tanpa perlu merubah sintaks coding. Hardware juga dapat terkoneksi ke jaringan secara nirkabel tanpa perlu menarik kabel jaringan. Penyebaran beberapa hardware yang terhubung pada suatu jaringan nirkabel nantinya akan membentuk Wireless Sensor Network (WSN) (Banu Santoso et al., 2014).

\section{METODE}

Perancangan hardware sistem monitoring meliputi perancangan hardware dengan diagram blok hardware, menentukan spesifikasi sensor-sensor, dan perancangan web konfigurasi hardware sistem monitoring.

\section{Rancangan Hardware Sistem Monitoring Portabel}

Diagram blok hardware sistem monitoring portabel dapat dilihat pada Gambar 1. Inputan hardware sistem monitoring terdiri dari 4 buah sensor arus, 1 buah sensor tegangan, 4 buah push button. Prosessor menggunakan Raspberry $\mathrm{Pi} 2$ model B 1GB RAM, sistem operasi Raspbian, dengan fasilitas 40 pin GPIO serta software pengolah data inputan sensor.

Output hardware sistem monitoring meliputi 1 buah LCD karakter 16x4 serta aplikasi web yang menampilkan hasil pembacaan sensor serta untuk mengkonfigurasi hardware. Bagian komunikasi meliputi port RJ45 (pada 
Raspberry $\mathrm{Pi}$ ) dan USB WiFi adapter berfungsi untuk menangkap, mengenali, mengirim, dan menerima data, ke dan dari jaringan melalui router.

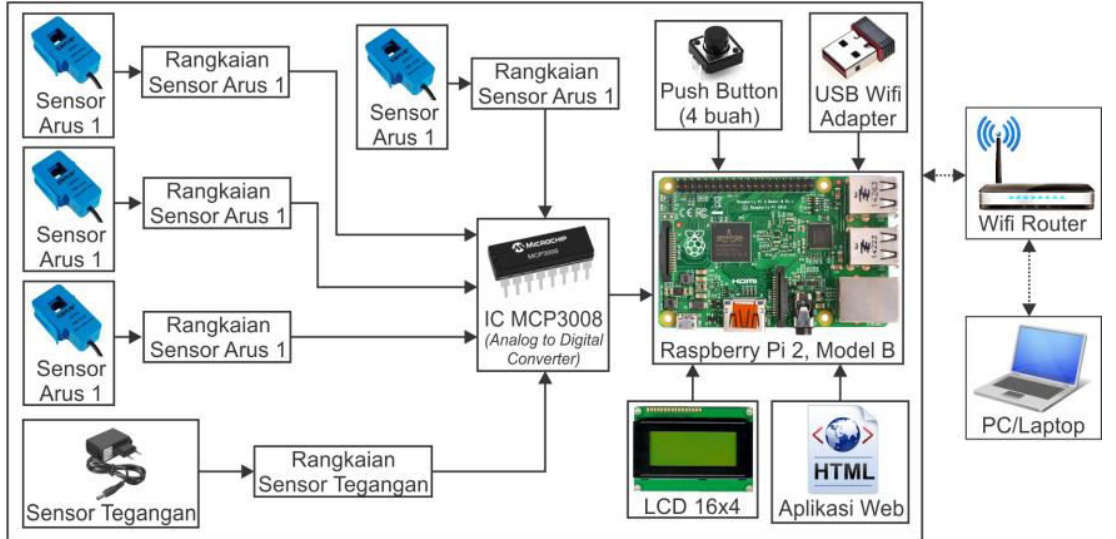

Gambar 1. Rancangan hardware sistem monitoring portabel

Prosessor

Prossesor hardware sistem monitoring portabel menggunakan Raspberry $\mathrm{Pi}$ dengan supply tegangan 5 Volt (Adafruit, 2017). Fasilitas GPIO digunakan sebanyak 14 pin dengan rincian 4 pin untuk IC MCP3008, 4 pin utuk tombol, dan 6 pin untuk LCD karakter $16 \times 4$. Prosessor mengolah data inputan sensorsensor yang telah dikonversi IC MCP3008 melalui proses Analog to Digital Converter (ADC). IC MCP3008 memiliki 8 channel inputan dengan resolusi 10 bit data digital (Microchip, 2008). IC MCP3008 terhubung ke Raspberry Pi melalui 4 pin GPIO yakni SPI_CE0, MISO, MOSI dan SCK.

\section{Sensor Arus}

Sensor arus digunakan untuk membaca arus listrik AC yang mengalir pada kawat penghantar instalasi listrik 3 fase. Hardware sistem monitoring portabel menggunakan sensor arus YHDC Current Transformer tipe SCT-013-000V sebanyak 4 buah. YHDC CT SCT-013-000V dipilih karena memiliki jangkauan pembacaan arus AC 0-100 Ampere dengan hasil pembacaan berupa tegangan 0-1Volt (Beijing YaoHuadechang Electronic Co., 2011). Turn ratio dari YHDC CT SCT-013000V yakni 100:1A. Rangkaian skematik sensor arus dapat dilihat pada Gambar 2.

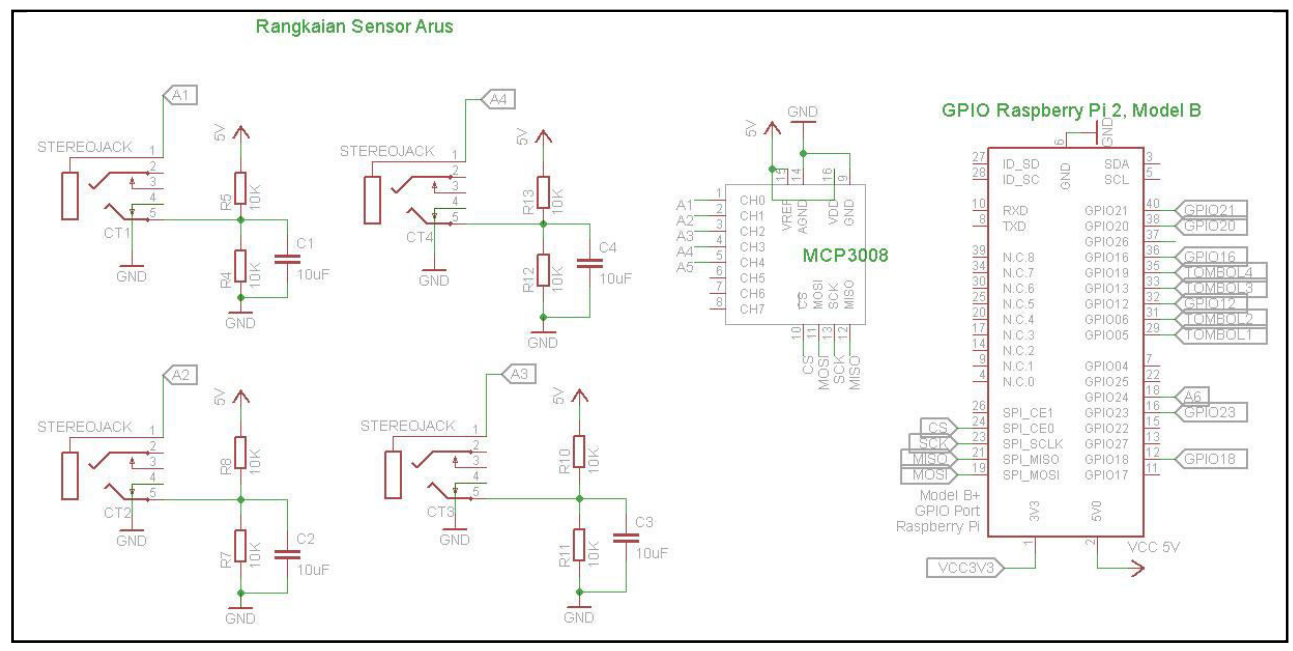

Gambar 2. Rangkaian skematik sensor arus

Sensor arus YHDC CT SCT-013-000 menggunakan tegangan suplai $5 \mathrm{~V}$ serta terhubung seri dengan rangkaian pembagi tegangan. Sensor arus YHDC CT SCT-013000V terhubung dengan pin $\mathrm{CHO}$ IC MCP3008. Output hasil pembacaan dari 0- 
1Volt dikonversi menjadi data digital 10bit rentang 0-1024.

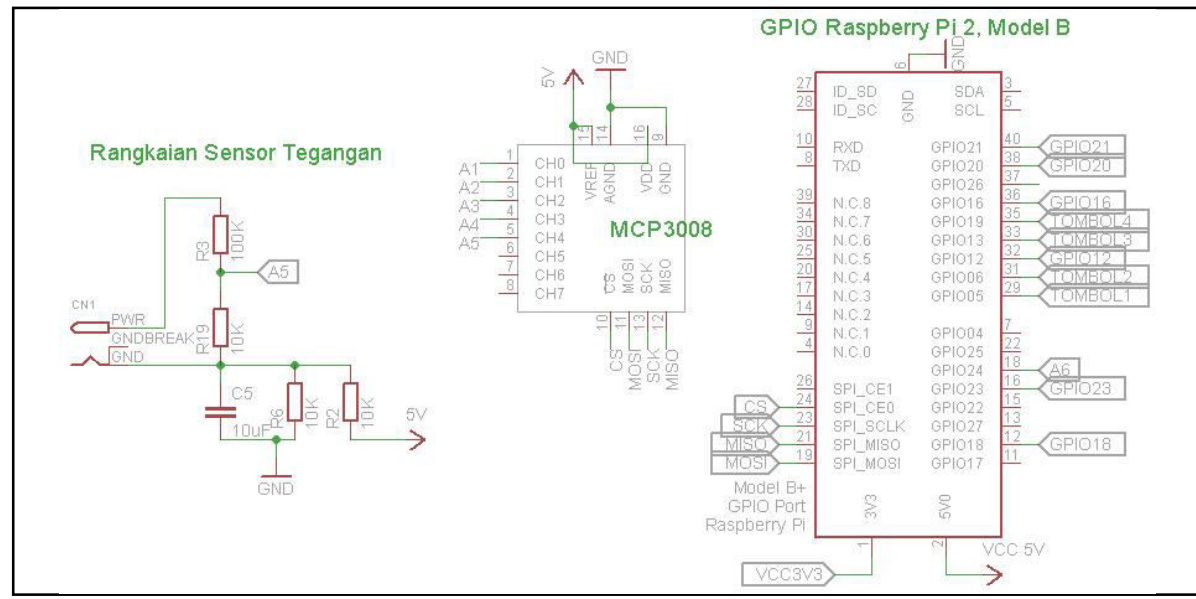

Gambar 3. Rangkaian skematik sensor tegangan

\section{Sensor Tegangan}

Sensor tegangan digunakan untuk membaca tegangan listrik $A C$ yang mengalir pada pada saluran kawat penghantar instalasi. Sensor tegangan hardware sistem monitoring portabel menggunakan transformator step down untuk menurunkan tegangan $A C 220 \mathrm{~V}$ yang berasal dari sumber menjadi tegangan $A C$ $6 \mathrm{~V}$. Output transformator terhubung dengan dioda bridge yang mengkonversi tegangan AC menjadi tegangan DC (Electrical4u, 2017). Tegangan DC melewati rangkaian resistor pembagi tegangan yang merubah tegangan DC 6Volt menjadi tegangan yang lebih kecil (JIMB0, 2017). Tegangan output pembagi tegangan dirumuskan pada Persamaan (1).

$V_{\text {out }}=V_{\text {in }}\left(\frac{R_{2}}{R_{1}+R_{2}}\right)$

Rangkaian skematik sensor tegangan dapat dilihat pada Gambar 3. Output tegangan DC 6Volt $\left(\mathrm{V}_{\text {in }}\right)$ melewati rangkaian pembagi tegangan menggunakan resistor 1 $\left(R_{1}\right) 10 \mathrm{~K}$ Ohm, resistor $2\left(R_{2}\right) 10 \mathrm{~K}$ Ohm dan menghasilkan tegangan output ( $\left.\mathrm{V}_{\text {out }}\right)$ sebesar 3Volt dihitung menggunakan Persamaan (1).

Output rangkaian sensor tegangan terhubung dengan pin $\mathrm{CH} 4$ IC MCP3008. IC MCP3008 mengkonversi data analog sensor tegangan $0-3$ Volt menjadi data digital 10bit rentang 0-1024 yang menggambarkan tegangan 0-220Volt.

\section{Rancangan Web Konfigurasi Hardware Sistem Monitoring Portabel}

Web konfigurasi hardware adalah sebuah antarmuka aplikasi web yang digunakan untuk melakukan konfigurasi konektivitas hardware ke jaringan dan menampilkan nilai hasil pembacaan sensorsensor. Urutan proses dalam web konfigurasi hardware dapat dilihat pada Gambar 4.

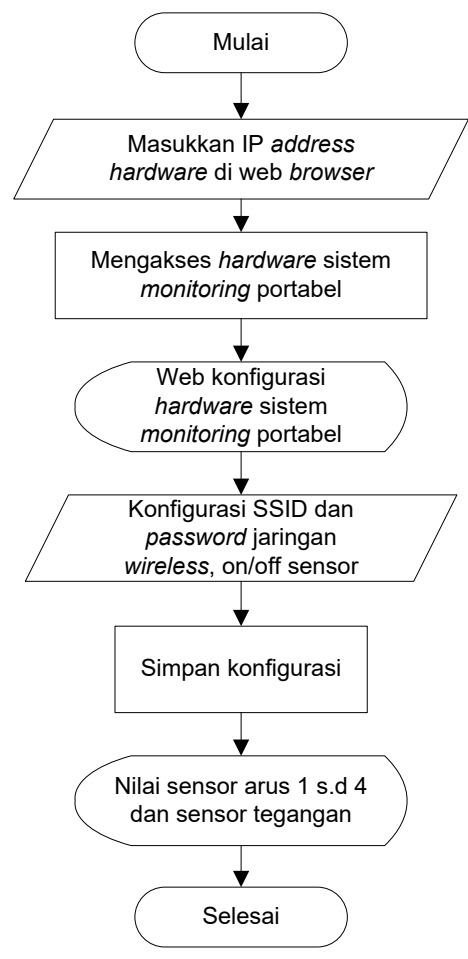

Gambar 4. Diagram alir antarmuka konfigurasi hardware

Jurnal Sains dan Teknologi | 4 
Urutan proses untuk mengakses web konfigurasi hardware sistem monitoring portabel dimulai dari menghubungkan hardware ke komputer/laptop menggunakan kabel UTP. Ketik IP address hardware pada web browser komputer/laptop. Pada web browser akan muncul antarmuka web konfigurasi hardware sistem monitoring portabel.

Pengaturan konektivitas hardware ke jaringan wireless dilakukan dengan menginputkan SSID dan password jaringan wireless. Pengaturan on/off channel sensor-sensor dilakukan dengan pilihan radio button masing-masing sensor yakni 1 sampai 4 sensor arus dan sensor tegangan. Simpan konfigurasi konektivitas jaringan wireless dan sensor-sensor. Nilai hasil pembacaan sensor arus 1 sampai dengan 4 dan sensor tegangan akan tampil pada web konfigurasi hardware sistem monitoring portabel.

\section{HASIL DAN PEMBAHASAN}

Pembahasan bagian ini meliputi realisasi rancangan hardware sistem monitoring portabel, realisasi rancangan web konfigurasi hardware sistem monitoring portabel, pengujian dan kalibrasi sensor-sensor hardware sistem monitoring portabel serta pengujian web konfigurasi hardware sistem monitoring portabel.

\section{a. Realisasi Hasil Rancangan Hardware} Sistem Monitoring Portabel

Realisasi hasil rancangan hardware sistem monitoring portabel dapat dilihat pada Gambar 5, Gambar 6 dan Gambar 7.

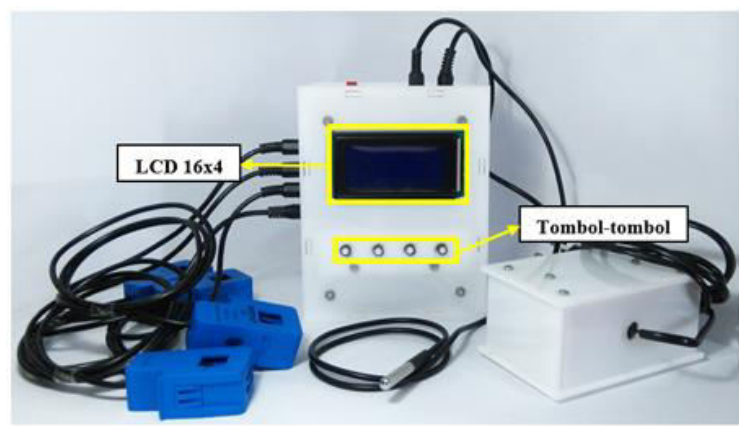

Gambar 5. Hardware sistem monitoring portabel

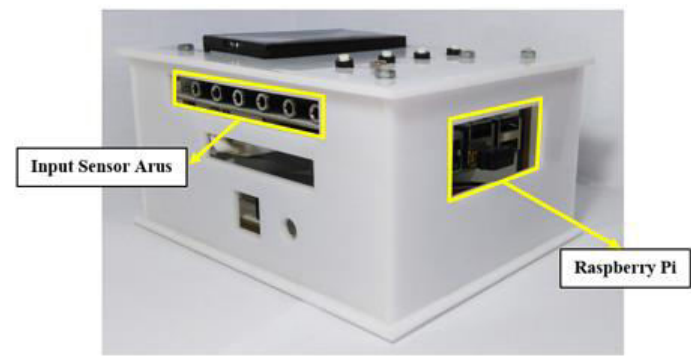

Gambar 6. Hardware tampak samping kiri

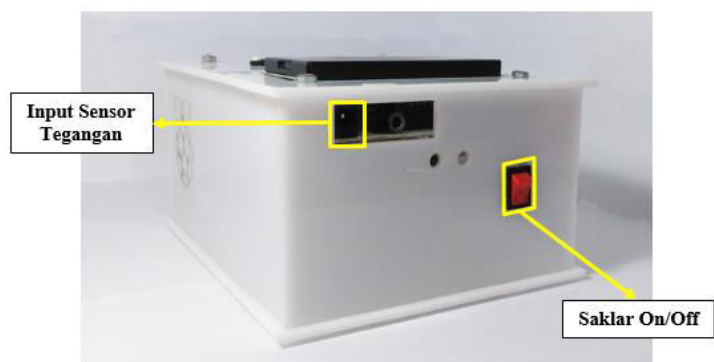

Gambar 7. Hardware tampak samping kanan

Hardware sistem monitoring portabel memiliki dimensi panjang $15 \mathrm{~cm}$, lebar $12 \mathrm{~cm}$ dan tinggi $8 \mathrm{~cm}$. Berat hardware sistem monitoring portabel dengan baterai mencapai 400gram. Sistem operasi Raspberry Pi 2, Model B, 1GB RAM yaitu Raspbian Jessie. Komunikasi wireless hardware sistem monitoring portabel menggunakan USB WiFi adapter 150Mbps, standard IEEE 802.11.

b. Realisasi Hasil Rancangan Web Konfigurasi Hardware Sistem Monitoring Portabel

Web konfigurasi hardware sistem monitoring portabel terdiri dari beberapa halaman menu utama yaitu "Login", "Sistem", "Jaringan", "Sensor" serta beberapa fungsi utama diantaranya "Reboot", "Shutdown", "Reset" dan "Logout". Adapun tampilan web konfigurasi hardware sistem monitoring portabel dapat dilihat pada Gambar 8 sampai dengan Gambar 11.

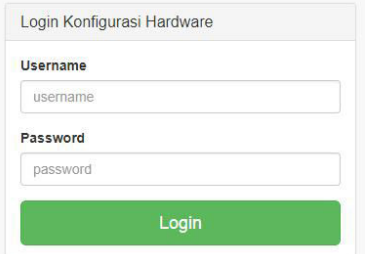


Gambar 8. Halaman "Login” web konfigurasi

hardware

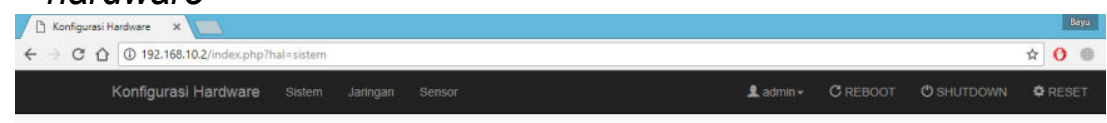

Informasi Hardware

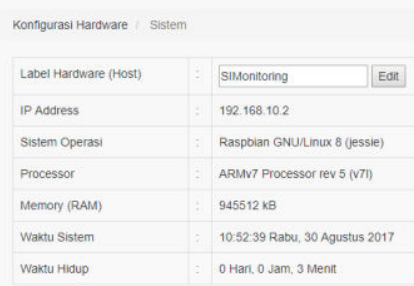

Gambar 9. Halaman menu "Sistem" web konfigurasi hardware

Halaman awal yang muncul saat web konfigurasi hardware sistem monitoring portabel pertama kali diakses adalah halaman "Login". Secara default "Label Hardware (Host)" pada web konfigurasi hardware sistem monitoring portabel yakni "SIMonitoring". Konektivitas jaringan dapat dilihat pada Gambar 10, dimana tipe alamat
IP static dengan alamat IP 192.168.10.2, default gateway 192.168.10.1 dan subnet mask 255.255.255.0. Komputer yang hendak dikoneksikan dan mengkakses web konfigurasi hardware sistem monitoring portabel untuk pertama kali, alamat IP-nya disetting pada kelas IP yang sama, misalnya menjadi 192.168.10.3.

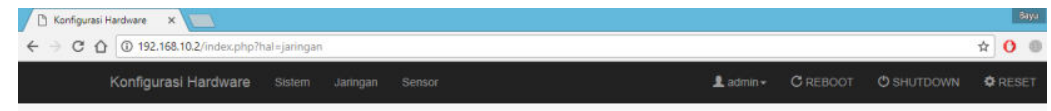

Informasi Jaringan

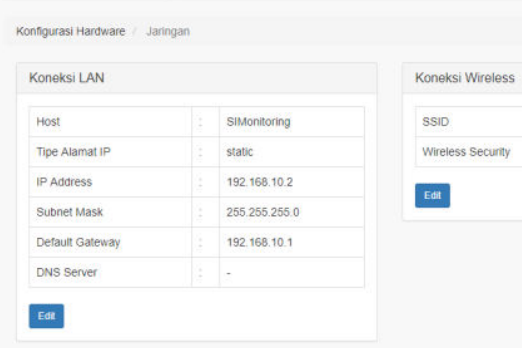

Gambar 10. Halaman menu "Jaringan" web konfigurasi hardware

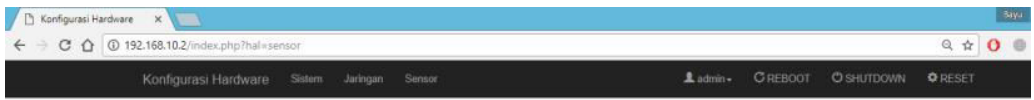

Konfigurasi Sensor dan Pengiriman Data
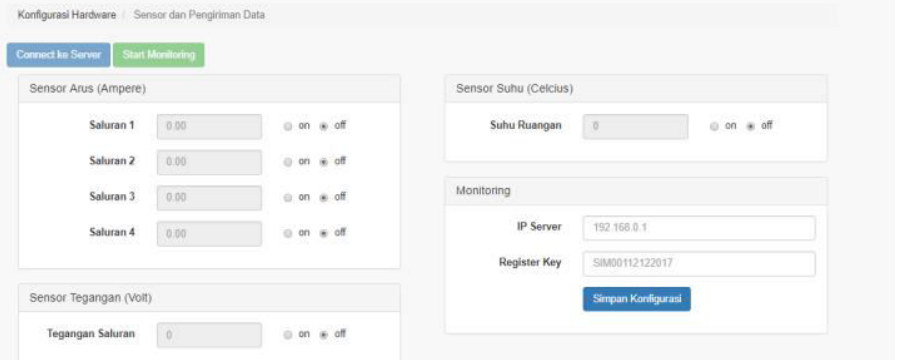

Jurnal Sains dan Teknologi | 7 
Gambar 11. Halaman menu "Sensor" web konfigurasi hardware

Gambar 11 menampilkan konfigurasi sensor arus dan sensor tegangan hardware sistem monitoring portabel. Untuk menampilkan nilai hasil pembacaan sensor arus dan sensor tegangan, rubah pengaturan option menjadi "on" pada "Saluran 1" sampai dengan "Saluran 4" dan "Tegangan Saluran".

\section{Tampilan LCD Hardware Sistem Monitoring Portabel}

Perangkat lunak atau software yang digunakan untuk mengolah data sensor arus, sensor tegangan serta tampilan LCD hardware sistem monitoring portabel menggunakan bahasa pemrograman Python. Tampilan awal dari interface LCD 16x4 pada Gambar 12 adalah tampilan yang terdiri dari 3 menu yaitu "Sens" (Sensor), "Net" (Network), "Sys" (System) serta waktu dan tanggal. Menu "Sens" diakses dengan menekan tombol 1 (paling kiri), menu "Net" diakses dengan menekan tombol 2, menu "Sys" diakses dengan menekan tombol 3 hardware sistem monitoring portabel. Untuk kembali ke menu awal dengan menekan tombol 4.

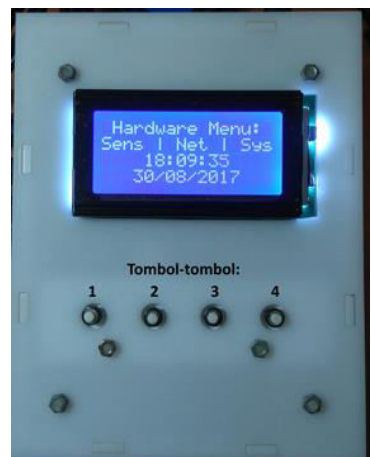

Gambar 12. Tampilan menu awal LCD hardware sistem monitoring portabel

Menu "Sens" menampilkan nilai hasil pembacaan sensor-sensor. Tampilan menu "Sens" dapat dilihat pada Gambar 13. Nilai pembacaan sensor arus ditandai dengan tulisan "CT1" sampai dengan "CT4" dalam satuan Ampere dan hasil pembacaan sensor tegangan ditandai dengan tulisan "V" dalam satuan Volt.

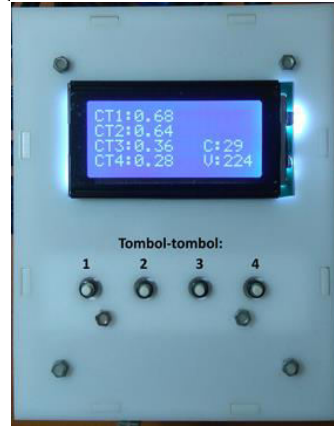

Gambar 13. Tampilan menu "Sens"

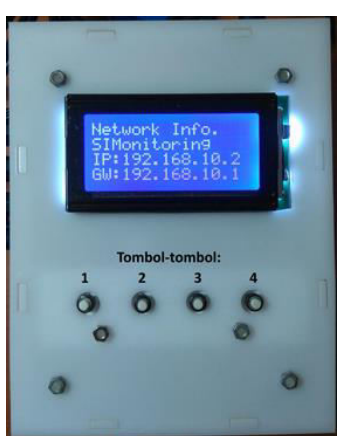

Gambar 14. Tampilan menu "Net"

Menu "Net" menampilkan informasi IP address dan IP gateway hardware sistem monitoring portabel. Tampilan menu "Net" dapat dilihat pada Gambar 14. Menu "Sys" untuk melakukan aksi shutdown dan reboot hardware sistem monitoring portabel. Tampilan menu "Sys" dapat dilihat pada Gambar 15. Aksi shutdown hardware dilakukan dengan menekan tombol 1 (paling kiri) hardware sistem monitoring portabel selama 5 detik. Aksi reboot hardware dilakukan dengan menekan tombol 2 hardware sistem monitoring portabel.

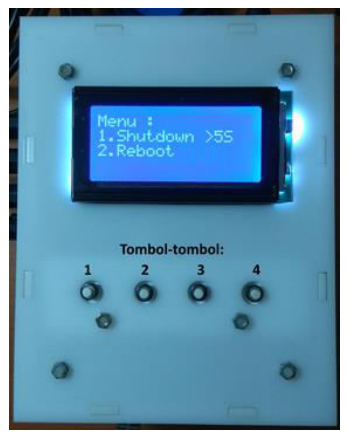

Gambar 15. Tampilan menu "Sys" 


\section{Pengujian Sensor Arus Hardware Sistem Monitoring Portabel}

Pengujian sensor arus tipe YHDC CT SCT-013-000 hardware sistem monitoring portabel dilakukan dengan membandingkan hasil pengolahan data inputan sensor arus yang tampil pada LCD dengan hasil pengukuran menggunakan clampmeter. Pengujian menggunakan 4 sensor arus pada panel saluran instalasi listrik sistem 3 fase Laboratorium Dasar Teknik Elektro
Fakultas Teknik Universitas Udayana, dengan membaca arus AC yang mengalir pada penghantar R-S-T-N. Tabel 1 menyajikan data hasil pengujian sensor arus. Persentase kesalahan (\% Error) dihitung menggunakan Persamaan (2).

$\%$ Error $=\left|\frac{\text { nilai clampmeter-nilai } L C D}{\text { nilai clampmeter }}\right| \times 100 \%$

Tabel 1. Hasil Pengujian Sensor Arus

\begin{tabular}{|c|c|c|c|}
\hline Penghantar & Nilai pada LCD (Ampere) & Clampmeter (Ampere) & $\%$ Error \\
\hline \multicolumn{4}{|c|}{ Sensor Arus 1} \\
\hline $\mathrm{N}$ & 0,37 & 0,28 & 32,14 \\
\hline $\mathrm{R}$ & 12,77 & 12,58 & 1,51 \\
\hline $\mathrm{S}$ & 2,85 & 2,94 & 3,06 \\
\hline $\mathrm{T}$ & 15,35 & 15,24 & 0,72 \\
\hline \multicolumn{4}{|c|}{ Sensor Arus 2} \\
\hline $\mathrm{N}$ & 0,34 & 0,28 & 21,42 \\
\hline $\mathrm{R}$ & 12,79 & 12,58 & 1,66 \\
\hline $\mathrm{S}$ & 2,90 & 2,94 & 1,36 \\
\hline $\mathrm{T}$ & 15,27 & 15,24 & 0,19 \\
\hline \multicolumn{4}{|c|}{ Sensor Arus 3} \\
\hline $\mathrm{N}$ & 0,38 & 0,28 & 35,71 \\
\hline $\mathrm{R}$ & 12,74 & 12,58 & 1,27 \\
\hline $\mathrm{S}$ & 2,88 & 2,94 & 2,04 \\
\hline $\mathrm{T}$ & 15,17 & 15,24 & 0,45 \\
\hline \multicolumn{4}{|c|}{ Sensor Arus 4} \\
\hline $\mathrm{N}$ & 0,36 & 0,28 & 28,57 \\
\hline $\mathrm{R}$ & 12,76 & 12,58 & 1,43 \\
\hline $\mathrm{s}$ & 2,95 & 2,94 & 0,34 \\
\hline $\mathrm{T}$ & 15,12 & 15,24 & 0,78 \\
\hline
\end{tabular}

Hasil pengujian sensor arus yang disajikan pada Tabel 1 , menunjukkan nilai hasil pengolahan inputan sensor arus yang yang tampil pada LCD mendekati nilai yang ditampilkan clampmeter. Persentase kesalahan (\% error) terbesar dari keempat sensor yakni pada pengukuran penghantar $\mathrm{N}$. Hal ini menunjukkan bahwa komponen rangkaian sensor arus yang dirancang memiliki sensitivitas yang kurang baik dalam pembacaan arus yang sangat kecil.

\section{Pengujian Sensor Tegangan Hardware Sistem Monitoring Portabel}

Pengujian sensor tegangan hardware sistem monitoring portabel membandingkan hasil yang tampil pada LCD dengan hasil pengukuran multimeter digital. Pengujian sensor tegangan dengan memvariasikan tegangan $\pm 5 \%$ dari batas tegangan efektif 220 Volt menggunakan modul experimental transformer yang terdapat di Laboratorium Konversi Energi Fakultas Teknik Universitas Udayana.

Tabel 2. Hasil Pengujian Sensor Tegangan

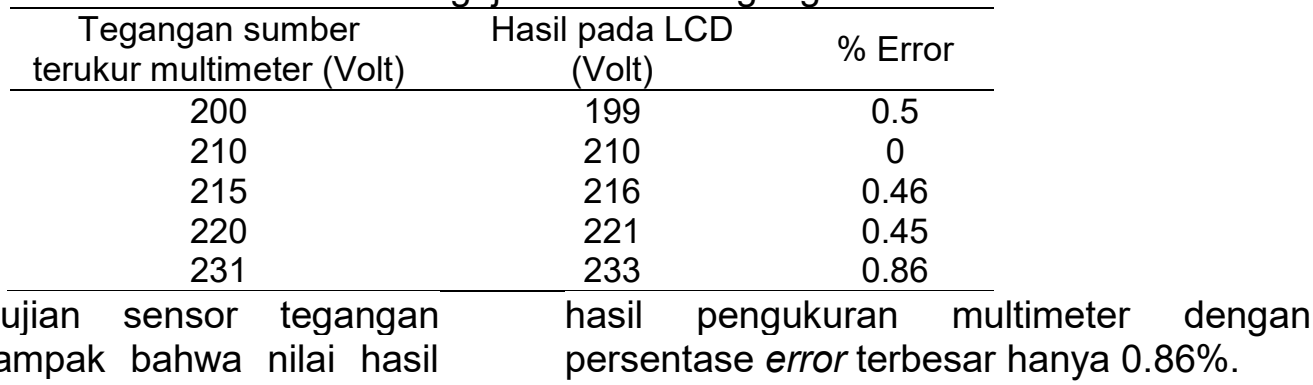

pada Tabel 2, tampak bahwa nilai hasil pengolahan inputan sensor tegangan yang tampil pada LCD hampir sama dengan nilai 


\section{Pengujian Web Konfigurasi Hardware Sistem Monitoring Portabel}

Pengujian web konfigurasi hardware sistem monitoring portabel menggunakan metode black box, dimana tanpa memperhatikan struktur atau alur internal dari kode program namun menitik beratkan pada pengujian fungsionalitas sistem (Kumar, Singh, \& Dwivedi, 2015). Pengujian meliputi proses login, mengkoneksikan hardware dengan jaringan wireless, menampilkan hasil pembacaan sensorsensor, reboot hardware, shutdown hardware, logout dan reset hardware. Hasil pengujian disajikan pada Tabel 3 sampai dengan Tabel 6.

Tabel 3. Pengujian Halaman "Login"

\begin{tabular}{|c|c|}
\hline \multicolumn{2}{|c|}{ Pengujian Login User (Data Benar) } \\
\hline $\begin{array}{l}\text { Prosedur } \\
\text { pengujian }\end{array}$ & $\begin{array}{l}\text { - Akses web konfigurasi hardware } \\
\text { sistem monitoring portabel } \\
\text { - Isi form username dan password } \\
\text { - } \text { klik tombol login }\end{array}$ \\
\hline Masukan & $\begin{array}{l}\text { - username "admin" } \\
\text { - password "admin" }\end{array}$ \\
\hline $\begin{array}{l}\text { Keluaran } \\
\text { yang } \\
\text { diharapkan }\end{array}$ & $\begin{array}{l}\text { Tampil halaman informasi jaringan } \\
\text { web konfigurasi hardware sistem } \\
\text { monitoring portabel }\end{array}$ \\
\hline $\begin{array}{l}\text { Hasil yang } \\
\text { didapat }\end{array}$ & $\begin{array}{l}\text { Halaman informasi jaringan web } \\
\text { konfigurasi hardware sistem } \\
\text { monitoring portabel }\end{array}$ \\
\hline Kesimpulan & Berhasil \\
\hline \multicolumn{2}{|c|}{ Pengujian Login User (Data Salah) } \\
\hline $\begin{array}{l}\text { Prosedur } \\
\text { pengujian }\end{array}$ & $\begin{array}{l}\text { - Akses web konfigurasi hardware } \\
\text { sistem monitoring portabel } \\
\text { - Isi form username dan password } \\
\text { - } \text { klik tombol login }\end{array}$ \\
\hline Masukan & $\begin{array}{l}\text { - username dan password kosong } \\
\text { - username "admin123" dan } \\
\text { password "admin" }\end{array}$ \\
\hline $\begin{array}{l}\text { Keluaran } \\
\text { yang } \\
\text { diharapkan }\end{array}$ & Muncul pesan peringatan kesalahan \\
\hline $\begin{array}{l}\text { Hasil yang } \\
\text { didapat } \\
\text { Kesimpulan }\end{array}$ & $\begin{array}{l}\text { Pesan "Peringatan! Username atau } \\
\text { Password salah" } \\
\text { Berhasil }\end{array}$ \\
\hline
\end{tabular}

Berdasarkan hasil pengujian halaman "login" pada Tabel 3, dapat disimpulkan fungsionalitas login telah sesuai dengan rancangan dan berfungsi dengan baik. Saat pertama kali melakukan login, user cukup menginputkan "username" dan "password" dengan teks "admin".

Tabel 4. Pengujian Halaman

"Koneksi Wireless"

Pengujian SSID Jaringan (Data Salah)

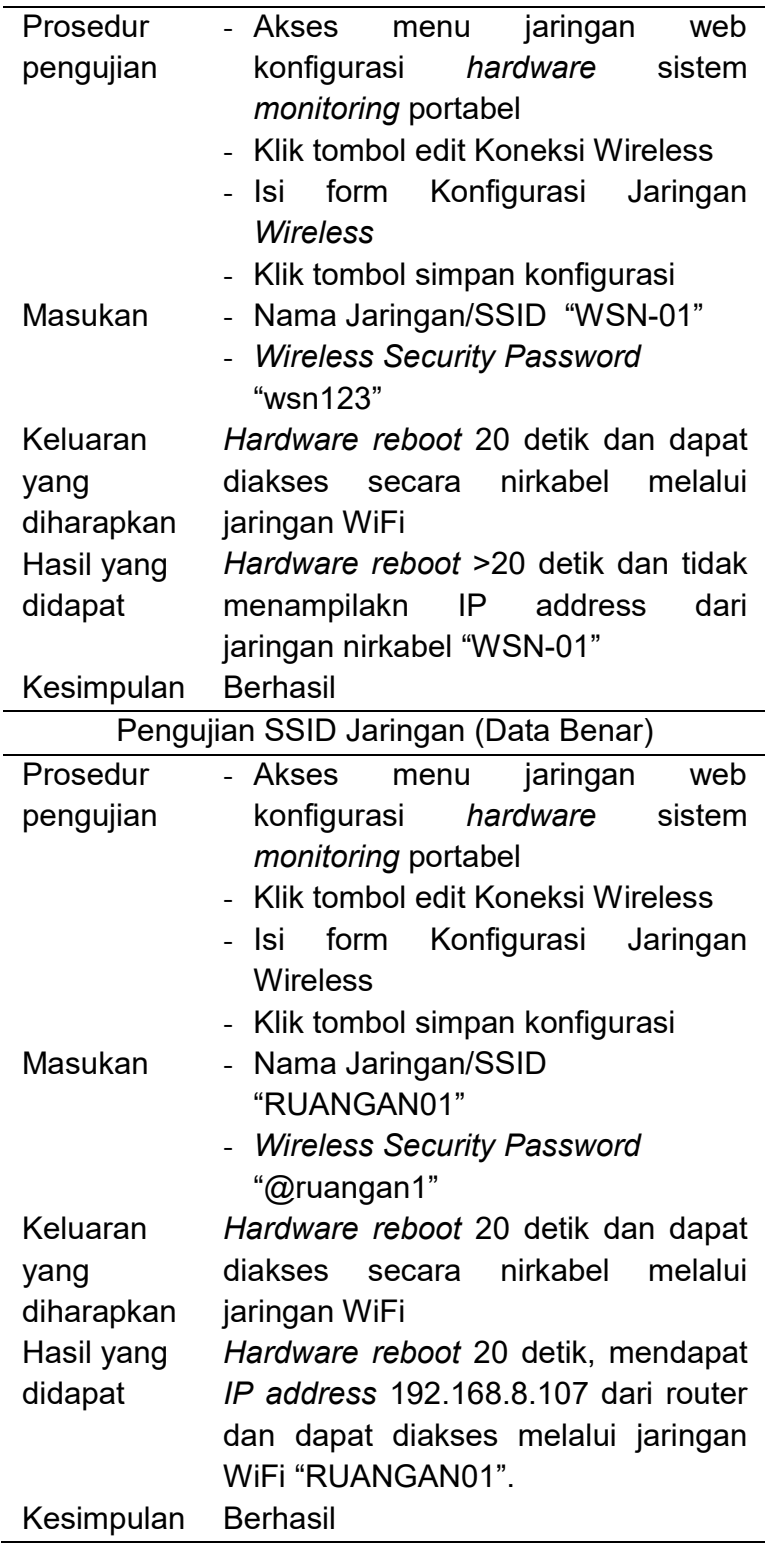

Hasil pengujian halaman "koneksi wireless" web konfigurasi hardware sistem monitoring telah sesuai rancangan dan berfungsi dengan baik. Hardware sistem monitoring portabel tekoneksi jaringan WiFi "RUANGAN01" mendapat IP address 192.168.8.107. Selanjutnya user bisa mengakses web konfigurasi hardware melalui jaringan WiFi "RUANGAN01" seperti yang terlihat pada Gambar 16 .

Tabel 5. Pengujian Halaman

"Konfigurasi Sensor"

\begin{tabular}{ccc}
\hline \multicolumn{3}{c}{ Pengujian Konfigurasi Sensor (Option On) } \\
Prosedur & Akses menu sensor web \\
\hline & Jurnal Sains dan Teknologi | 10
\end{tabular}




\begin{tabular}{lll}
\hline pengujian & konfigurasi hardware sistem \\
& monitoring portabel \\
& - Klik option On untuk seluruh \\
& sensor-sensor \\
Masukan & - Klik tombol simpan konfigurasi \\
& - On sensor arus saluran 1-4 \\
Keluaran & - On sensor tegangan saluran \\
yang & Pesan "Sukses! Konfigurasi \\
diharapkan & - Tampil nilai hasil pembacaan \\
& sensor-sensor \\
Hasil yang & - Muncul Pesan "Sukses! \\
didapat & Konfigurasi berhasil disimpan" \\
& - Text box yang menampilkan nilai \\
Kesimpulan & Bensor-sensor \\
\hline
\end{tabular}

Hasil pengujian halaman "konfigurasi sensor" telah sesuai rancangan dan berfungsi dengan baik. Software, dalam hal ini dengan mengekseskusi script Phyton dapat mengolah data inputan sensor arus dan sensor tegangan kemudian mengirimkan ke web konfigurasi hardware sistem monitoring portabel. Adapun tampilan dari hasil pengujian konfigurasi sensor dapat dilihat pada Gambar 17.

Hasil pengujian fungsi reboot, shutdown dan reset yang pada Tabel 6 telah sesuai dengan rancangan serta keseluruhan fungsionalitas telah berjalan/berfungsi dengan baik. Tujuan dibuatnya menu "Reboot" adalah untuk memulihkan kondisi hardware jika terjadi error pada tampilan LCD hardware sistem monitoring portabel. Menu "Shutdown" bertujuan untuk untuk mematikan hardware sistem monitoring.

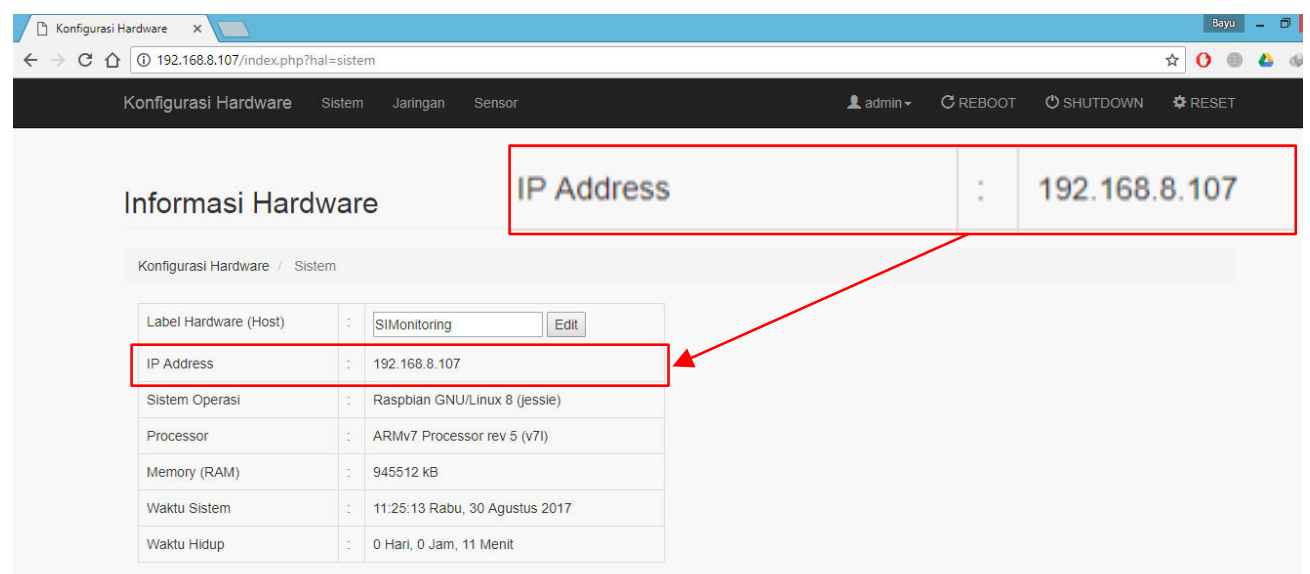

Gambar 16. Web konfigurasi hardware dengan IP address 192.168.8.107

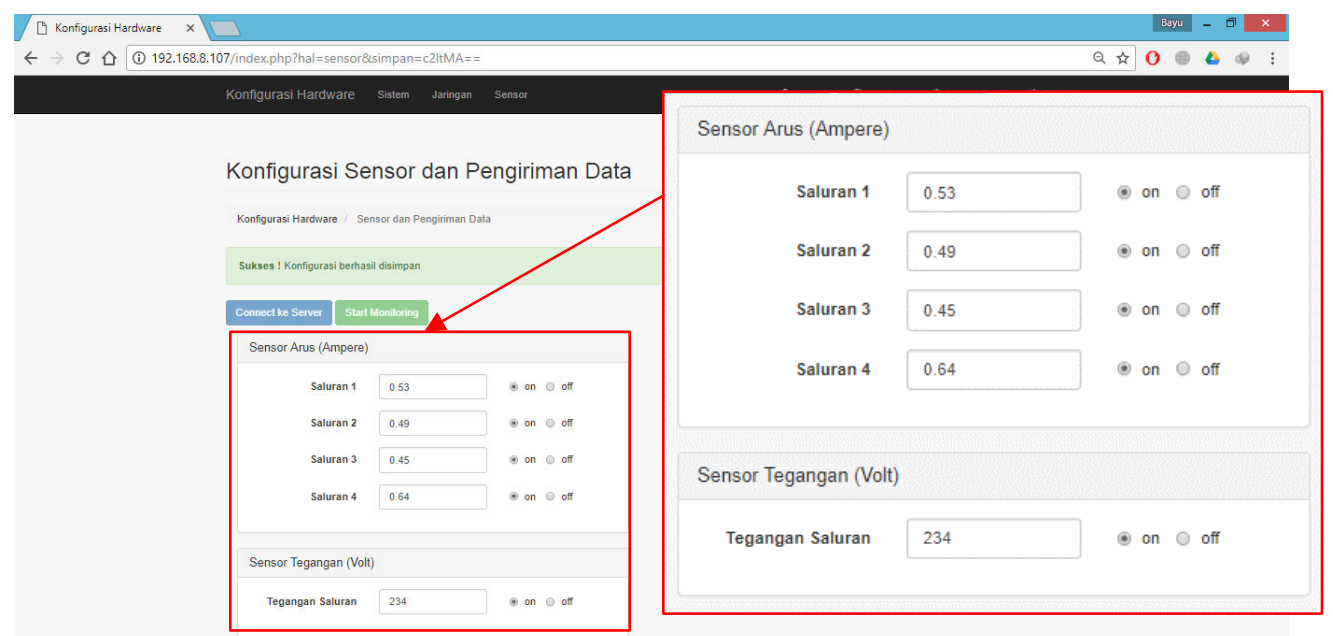

Gambar 17. Konfigurasi Sensor-sensor On 
Tabel 6. Pengujian Fungsi Reboot, Shutdown, dan Reset

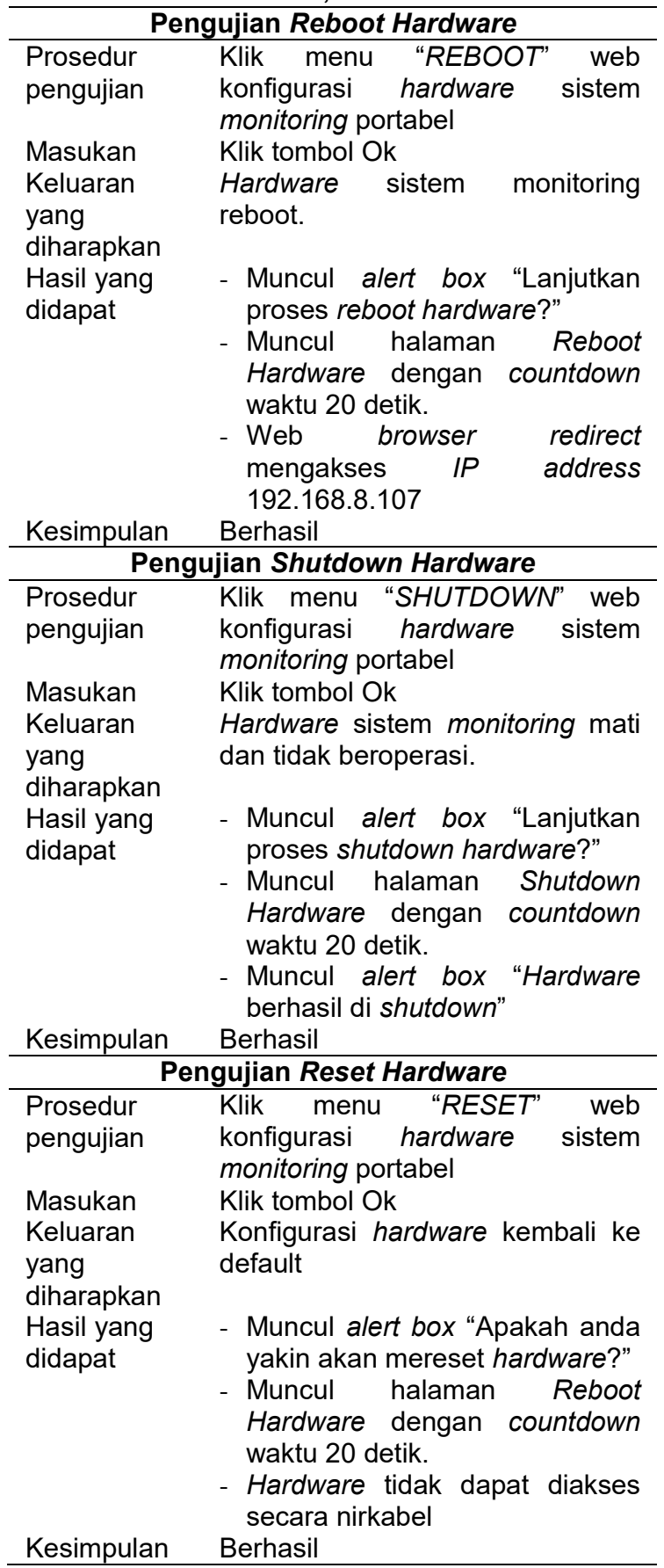

Menu "Reset" digunakan untuk mengembalikan konfigurasi hardware ke kondisi default jika ingin pindah ke lokasi pengukuran yang baru. Hasil pengujian fungsionalitas "Reboot", "Shutdown" dan "Reset" dapat dilihat pada Tabel 6.
Secara keseluruhan web konfigurasi hardware telah berjalan sesuai rancangan dan dapat menjalankan fungsionalitas dengan baik. Hardware dan web konfigurasi yang terintegrasi dapat diaplikasikan dengan mudah untuk memonitoring penggunaan listrik.

\section{SIMPULAN}

Hardware sistem monitoring portabel telah dirancang menggunakan Raspberry $\mathrm{Pi}$, sensor arus sensor arus YHDC CT SCT013-000 dan sensor tegangan AC. Hasil pengujian sensor arus YHDC CT SCT-013000 yang diujikan pada saluran listrik 3 fase RSTN didapatkan hasil persentase kesalahan terkecil pada pengukuran saluran $\mathrm{T}$ masing-masing sebesar $0.72 \%$ (Sensor Arus 1), 0,19\% (Sensor Arus 2), 0,45\% (Sensor Arus 3) dan 0,78\% (Sensor Arus 4). Persentase kesalahan terbesar pada pengukuran saluran $\mathrm{N}$ masing-masing sebesar 32,14\% (Sensor Arus 1), 21,42\% (Sensor Arus2), 35,71\% (Sensor Arus 3) dan $28,57 \%$ (Sensor Arus 4). Hasil pengujian sensor tegangan didapatkan persentase kesalahan pengukuran terkecil yaitu $0 \%$ pada pengukuran tegangan $210 \mathrm{~V}$ dan nilai terbesar $0.86 \%$ pada pengukuran 231V. Web konfigurasi hardware sistem monitoring portabel telah berhasil mengkonfigurasi hardware serta terhubung jaringan wireless "RUANGAN01" pada alamat IP 192.168.8.107. Hasil pengujian fungsionalitas login, koneksi hardware, konfigurasi "on" sensor reboot, shutdown, dan reset telah berjalan dengan baik dan sesuai rancangan.

Selanjutnya akan dikembangkan sebuah sistem informasi berbasis web yang digunakan untuk mengolah data hasil monitoring yang dikirimkan hardware sistem monitoring portabel penggunaan listrik. Selain itu hardware sistem monitoring portabel yang terintegrasi dengan sistem informasi dapat menyimpan dan menampilkan laporan hasil monitoring penggunaan listrik secara detail. 


\section{DAFTAR PUSTAKA}

Adafruit. (2017). Introducing the Raspberry Pi 2 - Model B. Diakses pada: https://learn.adafruit. com/introducingthe-raspberry-pi-2-model-b?view=all.

Banu Santoso, I Wayan Mustika, \& Sri Suning Kusumawardani. (2014). Pemodelan Monitoring Pemakaian Dan Penghematan Energi Listrik Dengan Teknologi Jaringan Sensor Nirkabel. Seminar Nasional Teknologi Informasi Dan Komunikasi, 2014(Sentika), 529-536.

Beijing YaoHuadechang Electronic Co., L. (2011). SCT013-000 Datasheet.

Edi Rakhman, Faisal Candrasyah, \& Fajar D. Sutera. (2014). Raspberry PiMikrokontroler Mungil yang Serba Bisa. Yogyakarta: Andi Offset.

Electrical4u. (2017). Bridge Rectifiers. Diakses pada: https://www. electrical4u.com/bridge-rectifiers/.

Ignatius Prima Haryo Prabowo, Saptadi Nugroho, Darmawan Utomo. (2014). Penggunaan Raspberry Pi Sebagai Web Server Pada Rumah Untuk Sistem Pengendali Lampu Jarak Jauh Dan Pemantau Suhu. Techné Jurnal IImiah Elektroteknika, 13(1), 111-124.
Irwan Dinata, \& Wahri Sunanda. (2015). Implementasi Wireless Monitoring Energi Listrik Berbasis Web Database. Jurnal Nasional Teknik Elektro, 4(1), 83-88.

JIMB0. (2017). Voltage Dividers. Diakses pada: https://learn.sparkfun.com/ tutorials/voltage-dividers.

Kumar, M., Singh, S. K., \& Dwivedi, R. (2015). A Comparative Study of Black Box Testing and White Box Testing Techniques. International Journal of Advanced Research in Computer Science and Management Studies, 3(10), 32-44.

Mercy Corps. (2005). Design, Monitoring and Evaluation Guidebook.Microchip. (2008). 2.7V 4-Channel/8-Channel 10Bit A/D Converters with SPI Serial Interface, 1-40. Diperoleh dari: https://cdn-shop.adafruit.com/ datasheets/MCP3008.pdf

Tauriq Djasa Permana. (2014). Sistem Monitoring Menggunakan Mini PC Raspberry Pi. Teknik Komputer Unikom - Komputika, 3(1), 1-6. 